\title{
Polska frazeologia potoczna w rosyjskiej gwarze staroobrzędowców w Polsce
}

Staroobrzędowcy mieszkający w Polsce to potomkowie Rosjan, którzy sprzeciwili się reformie liturgicznej patriarchy Nikona w rosyjskiej Cerkwii prawosławnej w XVII wieku. Represje ze strony władz świeckich i cerkiewnych przyczyniły się do masowych migracji zwolenników starego obrzędu, których jednym z głównych kierunków stały się ziemie Rzeczypospolitej (Iwaniec 1977: 22).

Zamieszkujący tereny północno-wschodniej Polski staroobrzędowcy są dwujęzyczną społecznością. Ich bilingwizm związany jest z dyglosją. W zależności od sytuacji komunikacyjnej posługują się rosyjską gwarą lub językiem polskim. Wpływ na wybór języka ma także wiele innych czynników o charakterze socjolingwistycznym, m.in. wiek (zob. Гжибовский, Глушковский 2013). Wśród przedstawicieli starszego pokolenia jako podstawowy środek komunikacji wykorzystywana jest rosyjska gwara, w średnim pokoleniu — rosyjska gwara i język polski, w zależności od idiolektu, natomiast młodsze pokolenie posługuje się przede wszystkim językiem polskim, a znajomość rosyjskiej gwary ogranicza się w ich przypadku zazwyczaj do komunikatywnego minimum lub biernej znajomości.

Potoczny wariant języka uważany jest za odmianę o najszerszym rozpowszechnieniu społecznym. W niektórych kręgach stanowi podstawowy, a często nawet jedyny środek werbalnej komunikacji, w innych natomiast używa się go wyłącznie w określonych społecznie warunkach. Z wyjątkiem społeczności, w których duży nacisk kładzie się na porozumiewanie się tradycyjną gwarą, język potoczny jest zazwyczaj najwcześniej przyswajanym wariantem języka (Łuc, Bortliczek 2011: 14).

W przypadku młodszej części społeczności staroobrzędowców w Polsce, w której jeszcze do niedawna wkładano sporo wysiłku w zachowanie i kultywowanie rodzimej tradycji, między innymi przez posługiwanie się rosyjską gwarą i nauczanie jej dzieci, potoczna odmiana języka polskiego była najprawdopodobniej najszybciej przyswajana, zwłaszcza że młodzi staroobrzędowcy dorastali w środowiskach wiejskich, a języka polskiego na początkowym etapie uczyli się głównie przez kontakty 
z polskim otoczeniem. Nieco inaczej jest w wypadku starszego pokolenia starowierców - część z nich z językiem polskim zetknęła się dopiero na etapie szkoły podstawowej, a więc nauka polszczyzny rozpoczęła się od jej wariantu literackiego.

Mimo że staroobrzędowcy na terytorium Polski w jej obecnych granicach pojawili się stosunkowo dawno, bo pod koniec XVIII wieku, to jeszcze na początku $\mathrm{XX}$ wieku żyli w izolacji. Po odzyskaniu niepodległości przez Polskę doszło do częściowej intensyfikacji kontaktów z polskim otoczeniem, natomiast kulminacja tego zjawiska nastąpiła po drugiej wojnie światowej, między innymi z powodu konieczności funkcjonowania w polskim systemie administracyjnym oraz obowiązku szkolnego. Postępująca asymilacja w warunkach polsko-rosyjskiego kontaktu kulturowego doprowadziła także do wielu zmian w zakresie rosyjskiej gwary staroobrzędowców. W ciągu lat język polski coraz silniej oddziaływał na rosyjską gwarę, co widoczne jest we wszystkich warstwach języka. Najwięcej zmian spowodowanych wpływem polszczyzny obserwuje się w zakresie leksyki, w której występują liczne zapożyczenia i kalki językowe (zob. Paśko-Koneczniak 2011), oraz frazeologii, w której obrębie notuje się coraz więcej kalk i półkalk.

Celem niniejszego artykułu jest zaprezentowanie przykładów frazeologii potocznej noszącej znamiona polskiego wpływu językowego, odnotowanych w rosyjskiej gwarze staroobrzędowców mieszkających w Polsce, oraz ich analiza pod kątem strukturalnym i semantycznym.

Materiał zgromadzony na potrzeby niniejszej analizy został wyekscerpowany z nagrań rozmów z informatorami, przeprowadzonych podczas kilkunastu ekspedycji dialektologicznych do miejscowości zamieszkanych przez staroobrzędowców. Rozmowy te przeprowadzili w latach 1999-2017 pracownicy naukowi, doktoranci i studenci Uniwersytetu Mikołaja Kopernika w Toruniu.

Analiza pozwoliła na wyodrębnienie wśród frazeologizmów następujących grup tematycznych: 1) charakterystyka człowieka, 2) role kobiety i mężczyzny w rodzinie, 3) określenia zachowań i skłonności, 4) określenia stanów i częstotliwości, 5) elementy życia codziennego i otaczającej rzeczywistości, 6) wykształcenie i życie zawodowe.

W obrębie pierwszej grupy, opisującej cechy, temperament i usposobienie człowieka, wynotowano następujące przykłady:

(kto) pšetpotop 'ovyj ${ }^{1}$ - pol. (ktoś jest) przedpotopowy, żart. 'przestarzały, niedzisiejszy, staroświecki' [ASSPP] (K-I/K-I'2: j'ana pšetpotp' ovyja, bo

${ }^{1}$ Anna Pajdzińska tego typu jednostki, składające się z jednego wyrazu ze znaczeniem nacechowanym metaforycznie, nazywa wyrazami o znaczeniu frazeologicznie związanym: „Obszar przejściowy między leksemami a jednostkami frazeologicznymi stanowią wyrazy o znaczeniu frazeologicznie związanym, czyli takim, które jest realizowane w połączeniu ze ściśle określonymi (zwykle w postaci listy) słowami. Chociaż więc jeden komponent grupy syntaktycznej jest używany w swej funkcji prymarnej, związki wyrazowe mają faktycznie charakter nieswobodny" (Pajdzińska 1991: 15-16).

${ }^{2}$ Symbolami K i M we fragmentach wypowiedzi oznaczona została płeć informatora (odpowiednio: $\mathrm{K}$ - kobieta, $\mathrm{M}$ - mężczyzna), natomiast cyfry rzymskie określają przynależność pokoleniową (I - starsze pokolenie, II — średnie pokolenie, III — młodsze pokolenie). 
kad'ata tak b'yła i 'eta ast' ałośa / a ja pšetpotop' ovyja [...] i ja tak całe życie robię);

$s$ kat'oraj str'ony v'ećer zav'ejit - pol. z której strony wiatr zawieje 'o kimś zmiennym, dwulicowym' (M-II: ńe zn'aju što mńe 'utram atab'ij'ot, s kat'oraj str' ony v' 'ećer zav' 'ejit);

l' 'apkyje r'uk'i — 'o skłonności do pewnych czynności'; pol. lepkie ręce, rub. żart. 'kraść, być złodziejem' [ASSPP] (M-II: kak mechanik fśo rozebr' ał, to kak' uju zab'avku pr'ińeśl 'i čy što mńe, č asem to i p'istal 'et pr'ińes' ut 'o tak 'o, to chwila moment i razabr'al'i v dr' obnyj mak, nie zdążył dać v r'uk'i, už' e r'uk'i ś'ilna l' apkyje b'yl'i k razbir'ańiju);

v'yxavać na luá 'ej - pol. wychować na ludzi 'wychować kogoś dobrze, zgodnie z przyjętymi zasadami'; pol. wychować na ludzi (M-II: b'aba skaz'awa i muś'ewa być źź'ełana, 'al'i bynajmniej v'yxaval'i na luź'ej, a tap'er no ńikaw' o ńe no tap' 'er fśe što gar' ast sł' uxać ńe x'očut);

m'eć pad d'eklem — 'o osobie rozsądnej, myślącej, zaradnej'; pol. mieć pod deklem - 'mieć w głowie, zazwyczaj negatywnie o cudzych poglądach, decyzjach' (M-II: ńet ž' adnyx mał' odyx, s majev'o ročń ika ńikav'o ńe ast' ałaś, kto norm'alnyj što m' 'eł pad d'eklam to gavar' 'u to tam f́se pav'yježžal'i);

m'eć hopla - 'mieć osobliwe pomysły'; pol. mieć hopla 'być niezrównoważonym psychicznie, także mieć obsesję na punkcie czegoś' [CSPP] (M-II: mał'odyji b'yl'i to gar' 'u m' el'i hopla, a i vyž' ełyval'i tam 'o v nas no tam kak 'o ka mń'e to m'uśel'i pr'ixaž' ić što drug'oj z̧'eń g b'aćk'i pr'ixaź'il'i, što drug 'oj z' eń b'aćka r' 'em'eń br'ał i tak wamat'ał pa plač'ax);

st'aryj byk - pol. stary byk 'o mężczyźnie, który zachowuje się niewspółmiernie do swojego wieku' (M-II: v las'u tak'aja gar'a balš'aja b'ywa [...] na s'ank'i dvaj'ox i paj' exal'i f kust'y, źerev' 'an:aji s ank'i na pół, pat p' axu, paš'oł g b'aćk'i, tata p'apa źź' ełaj bo pałam'al'iś, st'aryji byk' 'i gavar' it j'eźźić na s'ankaf pa p'ać'ox).

W zebranych przykładach jest widoczna funkcja aksjologiczna, wartościująca. Jak zauważa M. Rak, z potocznej odmiany języka wyłania się obraz świata nastawiony na racjonalizm i pragmatyzm, z wyraźnie zaznaczonymi dychotomicznymi podziałami wartościującymi na to, co dobre (korzystne) i złe (niekorzystne), a jego elementy dotyczą przede wszystkim sytuacji z życia codziennego szarego człowieka, w których zajmuje on główne miejsce jako obiekt i wykonawca czynności. Frazeologia potoczna jest nośnikiem kultury ludowej i językowym sposobem jej wyrażania poprzez właściwą tej kulturze gwarę (por. Rak 2007: 7-8).

Kolejną grupę stanowią frazeologizmy określające role kobiety i mężczyzny w rodzinie: 
xt'op pav' 'in:a być sa štan 'am - pol. [chłop | mężczyzna powinien] nosić spodnie | nosić spodnie w związku 'mężczyzna powinien posiadać cechy przypisywane kulturowo mężczyznom - ma być męski, zdecydowany, szanowany' (M-II: to ja gavar' 'u to tak'oj jon j'eśća što ńikud'y, t'oka dom dom i d'om a b'ol'e ńikud'y, to ja gar' 'u tam ńet už'e ńe xł'op gar' 'u xłop pav' 'in:a być sa štan'am);

xłop ńe leg 'at - pol. reg. chłop nie legat 'o mężczyźnie, który ciężko pracuje, nie jest leniwy' (M-II: xłop ńe leg' at, št' o 'eta zn'ačyt, što xłop rab 'očyj); [o kobietach] v'ołas dałg 'oj, 'al'i r 'ozum kar 'otkyj - pol. baba ma włos długi, a rozum krótki 'długim włosom towarzyszy brak mądrości u osoby, która je nosi' [WSJP] (M-II: z b'abam j'eśća t'ak ń'e, v'ołas dałg'oj 'al'i r'ozum kar'otkyj a s xł'opam atvar' otna v'ołas kar' otkyj 'al'i r'ozum dałg'oj);

igr 'ać v b'aćku i v m'atku — pol. bawić się w ojca i matkę 'żartobliwe określenie zalotów' (M-II: ź ̧́'efkam j'eśća tak [...] a p'ośe pr'ix 'oźit par'a i čas i v b'aćku i v m'atku igr'al'i).

Z przytoczonych przykładów wynika poszanowanie dla tradycyjnego (patriarchalnego) modelu rodziny, w którym mężczyzna wiedzie prym i podejmuje decyzje oraz dokłada wszelkich starań, aby zapewnić rodzinie byt, zabezpieczyć ją materialnie. Obraz kobiet natomiast jest negatywny — ukazane są jako bezmyślne czy nawet głupie.

W zakresie frazeologizmów opisujących zachowania i skłonności człowieka odnotowano następujące przykłady:

m'eć dryg - 'nadawać się do pewnych zajęć, posiadać talent'; pol. mieć dryg — 'mieć zdolności, talent do czegoś' [ASSPP] (M-I: m' 'eła tak'oj dryg $\mathrm{k}$ 'etamu);

ić'ić na r'uku - pol. iść na rękę 'ułatwiać komuś coś, pomagać komuś w czymś, sprzyjać komuś' [ASSPP] (M-II: 'al'e ja pagavar' 'ił t'am s k'er' ovńikam, no pašl' 'i n'am na ruk'u to źź' ełal'i);

3’ ełać za pšyzvoj'itku - pol. robić za przyzwoitkę | robić za kogoś 'pracować w jakimś zawodzie, w charakterze kogoś' [ASSPP] (M-II: nu kak m'atka z b'aćkaj na krok mńe ńe atpušč 'al'i kud'y jan'y išl' 'i to i ja iš' oł, ja im ź' ełał b'yt:a za pšyzvoj'itku);

3'etać wymysty - pol. robić wymysły 'wymyślać niestworzone rzeczy, wymyślać coś dla zaspokojenia własnych kaprysów' (M-II: što ja b'udu tab' 'e wymysły h́' ełać);

vyź' etywać č udy — pol. wyczyniać cuda 'robić rzeczy dziwne, osobliwe, nieoczekiwane' [ASSPP] (M-II: b'yła mn'ok małaź' ožy, mn'ok małčań'at, 
mn'ok źefč'at i b'yła s k'im xaū'ić s k'im šal'eć przede wszystkim ń'e, a xaź' il'i to č'udy vyź' ełyval'i);

max 'ać ruk'oj — pol. machnąć | machać ręką (na coś) 'zrezygnować z czegoś, zlekceważyć coś' (M-II: zn'ali što z nas ńe b'uź'et inžyńer'of to tam pr'ipušč al'i, max 'al'i ruk'oj ńekat' oryji).

W zbiorze frazeologii potocznej określającej stany, miary i częstotliwość znalazły się dwa przykłady w obrazowy sposób odnoszące się do sfery związanej $\mathrm{z}$ rolnictwem:

l'ažać [i sp 'ać] att'ogam — pol. leżeć odłogiem 'lenić się, tracić czas, próżnować' (M-II: l' 'ag'eš i śp' 'iš att'ogam);

kakfk'er'aće — pol. jak w kieracie 'o ciężkiej pracy, dużym wysiłku' (M-II: paśiz' eć paplotkav 'ać i f́śo paš' oł dam 'oj p'ośe spać, na utra fst ańeš abr'atna, kak f k’er' aće paš' oł na rab'otu).

Jest to szczególnie interesujące ze względu na fakt, że zarówno dla mieszkańców polskich środowisk wiejskich, jak i dla społeczności staroobrzędowców rolnictwo od wieków stanowiło główne zajęcie i źródło utrzymania. Może to być jedno z ewentualnych wyjaśnień, dlaczego niektóre wyrażenia zostały przejęte $\mathrm{z}$ języka polskiego do gwary.

Wśród określeń stanów zarejestrowano również przykłady:

(što) im 'ejet r 'uk'i i n 'og'i - pol. (coś) ma ręce i nogi 'o czymś sensownym, dobrze zorganizowanym, przemyślanym, uporządkowanym' [ASSPP] (M-II: i paź' ełal'i i fśo x 'očym pačyń 'ić paź' ełać, štob 'eta im' 'eła i r'uk'i i n'ogi);

v'ołas z gt'ovy ńe spaว́ 'ot - pol. włos z głowy nie spadnie 'nic złego się nie stanie' (K-I: baj' 'uś, ja gavar' 'u, što nas tut m'ogut ub' 'ić, m'ogut fśo, ńikt'o vas ńe ub'ij'ot, ńikt'o, v'ołas vam z głav'y ńe spaź' ot);

adn 'oj nag 'oj na tym świecie — pol. jedną nogą na tym świecie, rub. żart. 'być bardzo chorym, bliskim śmierci' [ASSPP] (K-I: jan'a už' e toš adn'oj nag 'oj na tym świecie).

$\mathrm{W}$ analizowanym materiale pojawiły się także dwa przykłady określające miarę i częstotliwość:

č asta i g'usta — 'wskazanie na dużą liczebność zbioru/grupy; nierzadko, częstokroć'; pol. często gęsto 'nierzadko, częstokroć, wielokrotnie, nieraz' [SRPJP] (M-II: xoć na tur'ystaf to ńa m' ožna nar'ek'ać [...] č' asta i g'usta j'eśća ix i źim'oj i l'etam);

čer'es p' 'aty i źeś 'aty — pol. piąte przez dziesiąte 'lekceważąco o wykonywaniu czegoś niedokładnie, wybiórczo, byle jak' [SRPJP] (K-I: tak kak nap' 'isana b'yła f sk' ask'e ja tam č'er'es p' 'aty i źeś'aty t'olka ńe p'omńu). 
Kolejną grupę wydzieloną ze zgromadzonego zasobu frazeologii potocznej stanowią jednostki opisujące elementy otaczającej rzeczywistości. W tym zakresie odnotowany został przykład charakteryzujący drogę o bardzo zniszczonej nawierzchni, użyty w odniesieniu do ogólnego stanu dróg w Polsce na początku XXI wieku:

3'ura na 3́'ury 3́'uraj pagań 'anaja - pol. dziura na dziurze dziurą poganiana 'o drodze ze zniszczoną nawierzchnią' (M-II: f p'olšče to 3 'ura na ś'ury '3' uraj pagań'anaja);

oraz przykład traktujący o ogólnym poziomie życia w kraju i jego zacofaniu w stosunku do innych, zawierający porównanie do ludów Afryki:

sto got za mužynam: brud, smród i ubóstwo - pol. sto lat za Murzynami || brud, smród i ubóstwo 'pogardliwe określenie cech jakiegoś miejsca' [SRPJP] (M-II: a f p' olšče sto got za muž ynam: brud, smród i ubóstwo).

W powyższym przykładzie dwa frazeologizmy połączone zostały w jeden; z kontekstu wynika, że informator potraktował jeden z nich jako kontynuację drugiego.

W grupie frazeologizmów potocznych, związanych z wykształceniem i życiem zawodowym, znalazł się z kolei przykład oznaczający świadomość konsekwencji zaniedbań w edukacji, braku chęci do nauki:

ne xać 'et naś 'ić teczki, to m 'uśet naś 'ić m 'ešk' 'i - pol. nie chciało się nosić teczki, to trzeba nosić woreczki | kopać dołeczki 'konsekwencją niefrasobliwego podejścia do nauki jest konieczność podjęcia pracy fizycznej' (M-II: prawie tr'i g'oda m'ešk' 'i targ 'ał bo ńe xać' eł teczki naś'ić to m 'uśeł naś' ić m'ešk' 'i)

oraz przykłady odzwierciedlające zdolności i stosunek do nauki w szkole:

być art'om - pol. być orłem 'o człowieku inteligentnym, bystrym, z polotem' [por. ASSPP] (M-II: f šk'ol'e za gar'ast tam arł' om ńe był);

m'eć głov'u k na 'uk'i — pol. mieć głowę do czegoś 'mieć zdolności, talent do czegoś, dobrze orientować się w czymś' [ASSPP] (M-II: to gavar' 'u, k na'uk'i ńe za gar' ast m’eł głov'u).

W omawianym zbiorze odnotowany został także frazeologizm odnoszący się do pracy w wyuczonym zawodzie lub specjalizacji:

rab 'otać w swoim fachu — pol. pracować | robić w swoim fachu [ASSPP] (M-II: skończył szkołę [...] i rab'otajet w swoim fachu).

Z przytoczonego materiału leksykalnego wyraźnie wyłania się antropocentryzm, co jest charakterystyczne dla frazeologii potocznej, ponieważ zazwyczaj dotyczy ona sfer bliskich człowiekowi i odnosi się do podstawowych obsza- 
rów jego działalności. Pojawiają się więc odwołania do części ciała człowieka, przede wszystkim do głowy, rąk i nóg (np. lev'yje r'uk'i, l' apkaje r'uk'i, (što) im 'ejet r'uk'i i n'og'i, adn'oj nag 'oj na tym świecie, v'ołas z głav'y ńe spaź'ot), do części garderoby (np. $x t^{\prime}$ 'op pav' 'in:a być sa štan 'am), zatrudnienia w ogóle (np. rab 'otać w swoim fachu) czy rolnictwa jako typowego zajęcia (np. l'až 'ać [i sp 'ać] att'ogam). Opisywana frazeologia potoczna cechuje się także dużą obrazowością, odwołuje się do elementów rzeczywistości, które otaczają człowieka, są mu znane i towarzyszą każdego dnia. Na podstawie analizowanego materiału językowego można też stwierdzić, że ważną cechą pochodzącej z polszczyzny frazeologii potocznej, funkcjonującej w rosyjskiej gwarze, jest wartościowanie za jej pośrednictwem zjawisk i zachowań (funkcja aksjologiczna).

Przeprowadzona analiza materiału wykazała, że zakres semantyczny przejętych z polszczyzny potocznej do rosyjskiej gwary frazeologizmów niemal całkowicie pokrywa się ze znaczeniami funkcjonującymi w języku polskim. Wyraźne rozbieżności znaczeń gwarowych w stosunku do polskich pierwowzorów występują wyłączenie w trzech przypadkach (l' 'apkaje r'uk'i, m'eć pad d'eklam, č'asta i g'usta) i związane są najprawdopodobniej z błędną interpretacją poszczególnych frazeologizmów dokonaną przez informatorów.

$\mathrm{Na}$ uwagę zasługuje również to, że przykłady frazeologii potocznej pochodzącej z języka polskiego pojawiają się przede wszystkim w mowie przedstawicieli średniego pokolenia staroobrzędowców, co może świadczyć o większym stopniu integracji tej grupy wiekowej z polską kulturą i środowiskiem. Wynika to $\mathrm{z}$ całą pewnością także $\mathrm{z}$ faktu, że średnie pokolenie cechuje przejściowy charakter sytuacji językowej - generalnie rzecz ujmując, wykazują się oni lepszą znajomością polszczyzny niż generacja starsza oraz znacznie lepszą znajomością rosyjskiej gwary w porównaniu z pokoleniem młodszym.

Istotną kwestią jest struktura frazeologizmów potocznych przejętych z polszczyzny do rosyjskiej gwary. W zgromadzonym materiale wyróżnić można: frazeologiczne kalki, czyli - według Jerzego Obary — frazeologizmy „będące tłumaczeniami obcych wzorów" (Obara 1989: 74), oraz frazeologiczne półkalki, czyli frazeologizmy „częściowo thumaczone (na podstawie obcych wzorów)” (Obara 1989: 83). Za kalkę frazeologiczną można zatem uznać frazeologizmy odnotowane w rosyjskiej gwarze, które stanowią konsekwencję całościowego thumaczenia polskiego wzorca za pomocą elementów gwarowych i które przy tym nie mają prostych ekwiwalentów w rosyjskiej gwarze i ogólnym języku rosyjskim, np. v'ołas dałg 'oj, 'al'i r'ozum kar'otkyj, igr'ać v b'aćku i v m'atku, časta i g'usta, č'er'es $p$ 'aty $i$ źeś'aty. Natomiast jako frazeologiczne półkalki należy traktować frazeologizmy odnotowane w rosyjskiej gwarze, które stanowią konsekwencję częściowego thumaczenia polskiego wzorca. Wyróżnić można trzy rodzaje frazeologicznych półkalk: 1) półkalki ekwiwalentne, czyli swoiste kontaminacje frazeologizmu polskiego i rosyjskiego (odnotowany w rosyjskiej gwarze frazeologizm nosi znamiona wpływu polskiego, jednak ma prosty 
ekwiwalent w ogólnym języku rosyjskim), np. v'ołas z głav'yńe spaź' ot (ros. волос с головы не упадёт), 2) półkalki niemające rosyjskich ekwiwalentów, zbudowane z elementów gwarowych i zapożyczeń, np. 3́'ełać za pšyzvoj 'itku, l'ažać [i sp 'ać] att'ogam, 3) półkalki bez rosyjskich ekwiwalentów, w których skład leksykalny wchodzą elementy rodzime i polskie (nieadaptowane zapożyczenia lub wstawki polskie), np. m'eć dryg, adn 'oj nag 'oj na tym świecie.

Jak zatem wynika z przeprowadzonej analizy, opisane przykładowe frazeologizmy potoczne o polskiej proweniencji zazwyczaj przenoszone są do rosyjskiej gwary wraz z ich pierwotnym znaczeniem. Ich znajomość wśród staroobrzędowców oraz stosowanie $w$ granicach semantycznych określonych $w$ języku polskim świadczy o stosunkowo dobrej znajomości języka polskiego i związanego z tym „polskiego" sposobu postrzegania pewnych elementów rzeczywistości. W zgromadzonych przykładach gwarowych frazeologizmów potocznych odzwierciedlony jest antropocentryzm jako jedna z cech potocznego obrazu świata. Potoczność omawianej frazeologii związana jest także z obrazowością, obfituje w dychotomiczne opozycje pozytywnych i negatywnych charakterystyk. Polska frazeologia potoczna trafia do rosyjskiej gwary z pierwotnym znaczeniem, jest jednak dostosowywana do modelu gwarowego poprzez kalkowanie. Analizowany w tym artykule materiał słownikowy składa się właśnie z przykładów frazeologicznych kalk i półkalk o różnym składzie leksykalnym. Kalkowanie polskich frazeologizmów do rosyjskiej gwary staroobrzędowców i odzwierciedlanie ich za pomocą rodzimych elementów językowych świadczy o stosunkowo wysokim poziomie zaawansowania procesów adaptacyjnych i postępującej integracji z polskim otoczeniem językowo-kulturowym oraz o coraz większym znaczeniu polszczyzny w życiu tej wspólnoty, a także potwierdza tezę o hybrydyzacji rosyjskiej gwary.

\section{Wykaz skrótów}

ASSPP — Anusiewicz J., Skawiński J. (2000), Słownik polszczyzny potocznej, Wrocław.

CSPP — Czeszewski M. (2008), Stownik polszczyzny potocznej, Warszawa.

SRPJP — Nagajowa M. (2005), Stownik rymowanek potocznego języka polskiego, Warszawa.

WSJP — Wielki stownik języka polskiego, http://www.wsjp.pl/index.php?id_hasla=2746 (dostęp:

21 października 2018).

\section{Bibliografia}

Iwaniec E. (1977), Z dziejów staroobrzędowców na ziemiach polskich XVII-XX w., Warszawa.

Łuc I., Bortliczek M. (2011), Język uwikłany w ponowoczesność, Katowice.

Obara J. (1989), Teoretyczne problemy kalkowania, Wrocław.

Pajdzińska A. (1991), Wartościowanie we frazeologii, [w:] Wartości w języku i tekście, red. J. Puzynina, J. Anusiewicz, Wrocław, s. 15-28. 
Paśko-Koneczniak D. (2011), Wpływ polszczyzny na zasób leksykalny rosyjskiej gwary staroobrzędowców na Suwalszczyźnie, Torun.

Rak M. (2007), Językowo-kulturowy obraz zwierząt utrwalony w animalistycznej frazeologii gwar Gór Świętokrzyskich i Podtatrza, Kraków.

Гжибовский С., Глушковский М. (2013), Диглоссия и сферы употребления польского языка и русского говора в общине старообрядиев сувальско-августовского региона (Польша), [w:] Русские старообрядиы. Язык. Литература. История. Сборник статей к XV Международному съезду славистов, red. Л. Л. Касаткин, Москва, s. 379-389.

\section{Polish colloquial phraseology in the Old Believers Russian dialect in Poland}

\section{Summary}

The Old Believers in Poland are a bilingual community. They use Russian dialect and Polish language depending on the communicative situation. From the second half of the 20th century assimilative processes of the Polish language-cultural environment became more intense. Therefore, in their Russian dialect and culture a stronger influence of Polish elements is noticeable.

The aim of this article is to analyze meanings of examples of colloquial phraseology from the Polish language functioning in the Russian dialect of the Old Believers in Poland and to analyze the structure of phraseological units that are a consequence of the influence of the Polish language on the Russian dialect.

Keywords: Old Believers, Russian dialect, phraseology, Polish colloquial language, phraseological calque 